\title{
Growth Performance and Chemical Composition of Corn Seedlings (Zea mays L.) Under Salt Stress and Priming Conditions
}

\author{
Nieven O. Fathi ${ }^{1}{ }^{\text {a }}$; Aly A. Gaafar ${ }^{1}$
}

\begin{abstract}
A laboratory experiment was conducted to study the potential effects of salt stress and priming seeds in saline solution, on the growth index and plant chemical composition of the newely selected single corn (Zea mays L.) hybrid namely, SC. 166. For this purpose, the seeds were primed in $5 \mathrm{~g} / \mathrm{L} \mathrm{NaCl}$ solution for 12 hours .The seedlings were subjected to various levels of $\mathrm{NaCl}(0,1,2$, 4,6 , and $8 \mathrm{~g} / \mathrm{L}$ ), and analysis of the parameters related to germination, growth, and chemical composition was analyzed The results indicated that increasing salinity concentration significantly decreased germination percentage and vigor index of both primed and unprimed seeds. This reduction was higher for unprimed seeds compared to primed seeds. Also, the salinity stress exhibited significant inhibitory effects on radicle and plumule length, total dry weight and salt tolerance index (SI) for both primed and un-primed seeds. The results detected on plumule sodium content (PSC) showed successive Na accumulation, as the salinity stress increased. The opposite trend was observed for $\mathrm{K}^{+}$ accumulation when exposed to salinity. In general, total chlorophyll content was significantly decreased with increase of salinity levels from 0 to $8 \mathrm{~g} / \mathrm{L} \mathrm{NaCl}$ in primed and unprimed seeds. Similarly, the proline content in plants derived from primed seeds was much higher than that of unprimed seeds. In conclusion, seed priming with $\mathrm{NaCl}$ is might be considered an effective way to meet the demands of farmers during the installation of the cultivation in conditions under salt stress to improve growth performance and chemical composition of corn
\end{abstract}

Key Words: Priming, Salt stress, Corn seedling, Growth parameters, Chemical composition

\section{INTRODUCTION}

Corn is considered one of the most important cereal crops in Egypt, not only because of its value as a source of human nutritional supply, but also as an additive source of forage crops. Besides, its by-product is recentely applied as a supplemental fuel source (Ashraf and McNeally, 1990). Previous studies (Kronzucker and Britto 2011, Zhang and Shi 2013) have shown that the seed germination of corn was significantly affected by the successive application of poor water quality, acting to impose retardation in plant growth (Almansouri et al., 2001) and yield (Gupta and Huang 2014). Under such conditions, accumulation of salt in

\footnotetext{
${ }^{1}$ Soil Salinity Research Department; Soils, Water \& Environment Research Institute, Agricultural Research Center, Alexandria, (Egypt).

${ }^{a}$ Corresponding author: nieven74@yahoo.com

Received August 3, 2015, Accepted August 31,2015
}

soil rhizosphere and/or even along the soil profile are among of the determinal factors, acting to induce nutritional disorder, disturbance in the physiological and the biochemical processes in plant cells (Rateb, 2013; Maathuis et al. 2014).

Under saline conditions, Plants develop various physiological and biochemical mechanisms to maintain a relatively stable intracellular environment via accumulating various solutes (Gupta and Huang 2014, Roy et al. 2014). The osmotic adjustment in plants can maintain the uptake of water and the turgor of cell, allowing regular physiological metabolisms (Radić et al. 2013). Proline, as an important osmo-protectant, contributes to osmotic adjustment and protecting enzymes from oxidative damage under saline condition (Ashraf and Harris 2004, Gupta and Huang 2014). Osmotic and saline stresses are responsible for the inhibition and hindrance of germination and plant growth (Almansouri et al., 2001).

Seed priming or osmo-conditioning is considered one of the physiological methods that improve germination and stimulate plant growth performance (Cramer, 2002). Recently, it is being applied to overcome for the salinity problems in agricultural lands. The data reported by Neto and Tabosa, (2000) showed that priming seeds, either in water and /or in saline solution for a short-term period, entails the potential germination. In this regard, different substances were suggested to monitor the osmotic adjustement. Among of the proposed salts are $\mathrm{NaCl}, \mathrm{KNO}_{3}, \mathrm{ZnSO}_{4}, \mathrm{KCl}$, and $\mathrm{CaCl}_{2}$. Previous studies (Souguir et al., 2013) showed that priming seeds in $\mathrm{NaCl}$, improved the salt tolerance concept in many of vegetables and condiment crops. Other reports (Farooq et al., 2004 and Souguir et al., 2013) demonstrated that priming seeds ameliorated the germination percentage and plant development. The advantage of priming seeds was interpreted to the stimulatory effect on the synthesis of protein and enzymes during the metabolic process (Cramer, 2002 and Varier et al., 2010). Hence, priming of corn seeds in $\mathrm{NaCl}$ might contribute for better growth performance and yield production in salt-affected soils.

Based on the above cited facts, the purpose of this study was to evaluate the potential effects of salt stress 
and priming seeds in saline solution on the growth performance and plant chemical composition of the newely selected single corn hybrid, namely, SC. 166.

\section{MATERIALS AND METHODS}

\section{Experimental layout:}

A short-term laboratory experiment was initiated on May 21, 2015 for 2 weeks under room conditions in Alexandria city, Egypt, where the average day/night temperature ranged from 20 to 25 /from 14 to $18 \mathrm{C}^{0}$ ,respectively. To meet the objectives of the study, a $2^{2}$ factorial experiment was carried out to study the effect of salt stress and pre-soaking seeds in solution on the growth index, chemical composition of corn plant. The treatments are basically defined by 6 levels of salt stress, being $0,1,2,4,6,8 \mathrm{~g} / \mathrm{L} \mathrm{NaCl}$ and 2 conditional priming seeds in saline solution (priming and unpriming),were arranged in a complete randomized design with 3 replicates.

The single cross hybride corn (SC.166) which was recently developed by the Maize Research Institute, Agricultural Research Center, Ministry of Agriculture land and Reclamation (MALR) Egypt, was used to test its performance to salt stress at the earlier growth stage. In this respect, uniform $400 \mathrm{~g}$ of corn seeds, with similar size were screened and divided into 2-equal parts. The first part (200 g) of corn seeds was soaked in saline solution, containing $5 \mathrm{~g} / \mathrm{L} \mathrm{NaCl}$ for $12 \mathrm{~h}$. And the second part $(200 \mathrm{~g})$ was used as a reference for the relative evaluation (un-priming treatment). The respective pre-soaked salt-affected seeds were later, washed with tap water and dried at room temperature. To stimulate germination process and root development, uniform 60 of the soaked and /or un-priming salt treated seeds were rolled in filter paper sheets and placed in several beakers containing variable levels of $\mathrm{NaCl}$ concentrations. In all cases, the achievement of seed germination was, however, realized when the radical root emerged by about $2 \mathrm{~mm}$ in length (Ahmadvand et al., 2012). After 3 days from the beginning of germination, uniform 30 seedlings of priming and nonpriming seeds were carefully transplanted to plugged holes foam fitted in plastic pots $(40 \mathrm{~cm}$ diameter $\times 10$ $\mathrm{cm}$ height) containing the tested salt solution. The seedling were placed and partially immersed in the aerated solution with formentioned salt treatments for 2 weeks under room temperature. The growth media of salt-stressed plants were renewed, each 3 days, during the growth duration.

At the end of the experiment, the radicle and plumule were carefully separated from the seedlings, rinsed in distilled water and their fresh weight were measured .Plant materials were oven-dried at $65{ }^{\circ} \mathrm{C}$ for $48 \mathrm{hrs}$, grounded in a stainless steel mill and the oven- dried plant material was measured. Subsamples were dry-ashed in a muffle furnace at $450^{\circ} \mathrm{C}$ for $6 \mathrm{~h}$ and the ash was dissolved in $5 \mathrm{ml}$ water diluted $\mathrm{HNO}_{3}(1: 1)$ for measuring $\mathrm{K}^{+}$and $\mathrm{Na}^{+}$(Jones, 2001) by Jenway, PFP 7 flame photometer. Plumule proline content $\left(\mu \mathrm{g} . \mathrm{g}^{-1}\right.$ DW) was measured by spectrophotometer UV-visible based on its reaction with ninhydrin and the absorbance of the solution was read at $520 \mathrm{~nm}$ using toluene as a blank (Bates et al., 1973). The total chlorophyll content in corn leaves was measured by SPAD 502 Plus Chlorophyll Meter (Spectrum Technologies,Inc).

\section{Measurements of physiological parameters:}

I- Germination percentage (GP): The emergence of plumule was taken as an indication of germination process. Germination percentage was calculated according to the International Seed Testing Association method (ISTA, 2008), i.e

$\mathrm{GP}=$ (Number of normally germinated seeds / Total number of seeds sown) $\times 100$

II- Plumule and radicle length: Plumule and radicle length were measured on five randomly selected seedlings using transparent ruler from each treatment after 14 days of germination. Plumule length was recorded by the height of seedling from the surface of the foam to the tip of the plant top. The radicle length was measured from the point of first cotyledonary node to the tip of longest root. The length was expressed in cm plant ${ }^{-1}$.

III- Salt tolerance index (SI): This value was calculated as the ratio of total oven dry weight (TDW) of plants subjected to different salt concentrations $\left(\mathrm{S}_{\mathrm{x}}\right)$ to the total dry weight of plants of the control $\left(\mathrm{S}_{0}\right)$, i.e

SI $(\%)=\left(T D W\right.$ at $\mathrm{S}_{\mathrm{x}} / \mathrm{TDW}$ at $\left.\mathrm{S}_{0}\right) \times 100$

IV- Vigor index (VI): Seedling vigor index (VI) was calculated using the formula of Elouaer and Hannachi (2012) as follows.

$\mathrm{VI}=($ Germination percentage, $\% \times$ Plumule length, $\mathrm{cm})$ $/ 100$

\section{Statistical analysis}

All the recorded and measured data were subjected to the analysis of variance to test the significant differences between means at $p<0.05$ level (Duncan's multiple range, with the help of Cohort software, 1986 (COSTAT). LSD values were calculated.

\section{RESULTS AND DISCUSSION}

The main effects of salinity, priming and their interaction on:

\section{1- Growth parameters}

Growth parameters, in terms of germination percentage (GP), vigor index (VI), plumule and radicle 
length, total dry weight (TDW) and salt tolerance index (SI) are presented in Table (1).

\subsection{Germination percentage (GP) and vigor index (VI):}

The experimental data showed that increasing salinity levels from 0 to $8 \mathrm{~g} / \mathrm{L} \mathrm{NaCl}$ exerted marked variations in seed germination. At the lower salinity, up to $2 \mathrm{~g} / \mathrm{L} \mathrm{NaCl}$, the difference between means of GP were not significant $(p>0.05)$.At the highest salinity, particularly at $6 \mathrm{~g} / \mathrm{L} \mathrm{NaCl}$ and/or $8 \mathrm{~g} / \mathrm{L} \mathrm{NaCl}$, the GP were clearly impaired. Relative to the control treatment, the reductions in GP at the respective salinity were subsequently 9.5 and $21.5 \%$ ((Fig.1 A and Table 1$)$.

Regardless to the salt stress treatment, priming seeds in $5 \mathrm{~g} / \mathrm{L} \mathrm{NaCl}$ for $12 \mathrm{~h}$ was more superior to enhance all growth attributes than the non-priming seeds. Also, the effect of seed priming and interaction between salinity and priming levels were significant $(p>0.05)$. The highest germination percentage (97\%) was obtained with $0 \mathrm{~g} / \mathrm{L} \mathrm{NaCl}$ and the least were (93 and $57 \%$ ) at 8 $\mathrm{g} / \mathrm{L} \mathrm{NaCl}$ in primed and unprimed, respectively (Fig.1A).

The two-way interaction of salt exposure and seed priming treatment on the GP (Fig.1A) showed that priming seeds in saline solution was more pronounced along all salinity levels than the un-primed seeds. It is worthy to point out that differences in GP between the primed or un-primed seeds were not significant $(p>0.05)$ at the lower salinity levels up to $4 \mathrm{~g} / \mathrm{L} \mathrm{NaCl}$ (Fig.1A). However, at the higher salinity exposure, up to 6 and/or $8 \mathrm{~g} / \mathrm{L} \mathrm{NaCl}$, significant variation were detected. The data indicated that at any given salinity level, GP was more superior for the primed than the unprimed seeds, particularly, at the higher salinity levels.

The reduction in germination percentage occurred at high salinity levels was due to the adverse effect of high salinity on physiological processes which affected negatively seed germination (Khan et al., 2010).Also, this might be due to the toxic effects of $\mathrm{Na}^{+}$and $\mathrm{Cl}^{-}$in the process of germination (Khajeh-Hosseini et al., 2003).

Based on the analysis of variances, salinity level and seed priming have significant $(p<0.01)$ effect on vigor index (Table 1) but, their interaction was notsignificant. Increasing salinity caused a significant decrease $(p<0.01)$ in corn vigor index for both unprimed and primed seeds (Table 1 and Fig. 1). This decrease was, however, ranged from 33 at $0 \mathrm{~g} / \mathrm{L}$ to 2 at $8 \mathrm{~g} / \mathrm{L} \mathrm{NaCl}$ Primed seeds of corn might have better competency for water absorption from the growing media that enabled metabolic activities in seeds during germination process much earlier than radicle and plumule appearance (Elouaer and Hannachi, 2012).
Similarly increased solubilization of seed storage proteins like the beta subunit of the globulin and reduction in lipid peroxidation and enhanced antioxidative activity in primed seeds facilitated germination. This faster germination was due to the synthesis of DNA, RNA and protein during priming (Afzal et al., 2008).

The results outlined on VI (Fig.1B) indicated that the rate of decline in vigor index was quite different for the primed and un-primed seeds along the all salinity treatments, giving differential growth response. The LSD comparison proved that variation in VI between the primed and un-primed seeds exhibited marked significant differences at any level of salt stress. Similar results were found by Ruan et al. (2002) and Kader and Jutzi, (2004).

\subsection{Plumule and radicle lengths and the reciprocal ratio}

It is clear from Fig (2) and Table(1) that salinity had a significant inhibitory effect on plumule length (PL) for both primed and un-primed seeds. This effect was significantly $(p<0.01)$ in seedlings from $\mathrm{NaCl}$ primed and unprimed seeds. Similarly, salinity affected seedlings' radicle length (RL) of both primed and unprimed seeds of corn with increasing salinity levels and this influence was highly prominent on plumule and radicle lengths from unprimed seeds when compared to the primed ones. The highest reduction in radicle length and plumule (Fig. $2 \mathrm{~A}$ and B) was noted at $8 \mathrm{~g} / \mathrm{L} \mathrm{NaCl}$. At the higher salt exposure (at $4-8 \mathrm{~g} / \mathrm{L} \mathrm{NaCl}$ ), the radicle root was extremely impaired rather than plumule traits. Quantitavely, the relative drop in PL at 4,6 and 8 $\mathrm{g} / \mathrm{L} \mathrm{NaCl}$ were $80.2,83.3, \& 90.5 \%$, respectively .The values of comparable reduction in RL at respective salt exposure, subsequently were $95.0,95.7$ and $97.8 \%$.The calculated RL/PL ratio confirmed the serious effect of salt stress exposure on root growth and its development at the earlier growth stage of corn seedlings. In this study, seed priming significantly improved corn seedling growth at different salinity levels. Significant improvement in radicle and plumule length in the primed seeds may be attributed to earlier germination induced by priming (Farooq et al., 2005). During priming, the embryo expands and compacts the endosperm. The compaction force of the embryo and hydrolytic activities on the endosperm cell walls may change the tissues to have their flexibility upon dehydration, producing free space and facilitating root and seedling fast projection after rehydration (Mohammadi, 2009). This led to vigorous seedlings with more radicle and plumule length than the seedlings from unprimed seeds. The present results confirm the findings of Nawaz et al. (2012) in tomato (Lycopersicon 
esculentum Mill.) and in Canola (Brassica napus L.) where priming of the seeds significantly improved shoot and radicle length.

The analysis of variance indicated that salinity level, priming and their interaction exerted significant $(p<0.01)$ effects on radicle to plumule ratio. It was decreased significantly with increasing salinity level from $0 \mathrm{~g} / \mathrm{L}(1.31)$ to $8 \mathrm{~g} / \mathrm{L}(0.48)$, and the effect was more pronounced in unprimed seeds (Figure $2 \mathrm{C}$ ) since the RL/PL ratio was decreased significantly with increasing salinity level from $0 \mathrm{~g} / \mathrm{L}(1.24)$ to $8 \mathrm{~g} / \mathrm{L}$ (0.30). This study showed that salt stress had inhibited radicle growth more than primary shoot growth. Decreased RL/PL ratio with increasing salinity level could be due to the first exposition of the radicle to salinity which is rapidly affected before the plumule (Akram et al., 2010). Under saline conditions, $\mathrm{NaCl}$ priming increased radicle to plumule ratio of corn seedlings. High radicle to plumule ratio in primed seeds under salt stress may be considered important for salt tolerance of growth attributes (Alian et al., 2000). Thus, high radicle to plumule ratio in corn seedlings induced by priming in $\mathrm{NaCl}$ could be interned to the adaptation mechanism to salinity. The combined effect of the variable treatments on plumule and radicle performance along the salt exposure levels (Figs 2A, 2B) was more primitive for the primed than un-primed seed treatments. In other words, the pattern of PL and RL response exhibited similar reaction. The pronounced significant deviation in both traits were more abundant when the salinity levels ranged from 2 to $6 \mathrm{~g} / \mathrm{L} \mathrm{NaCl}$. The interaction study of the calculated RL/PL values (Fig 2C) followed up the same trend as for RL and PL.

\subsection{Total dry weight (TDW) and salt index (SI)}

The total dry weight decreased from $0.44 \mathrm{~g}$ at $0 \mathrm{~g} / \mathrm{L}$ $\mathrm{NaCl}$ to $0.06 \mathrm{~g}$ at $8 \mathrm{~g} / \mathrm{L} \mathrm{NaCl}$ and from $0.41 \mathrm{~g}$ at $0 \mathrm{~g} / \mathrm{L}$ $\mathrm{NaCl}$ to $0.03 \mathrm{~g}$ at $8 \mathrm{~g} / \mathrm{L} \mathrm{NaCl}$, in primed and unprimed seeds, respectively (Fig.3A). The difference in performance was significant at $99 \%$ confidence level. The reduction in TDW may be due to the reduction of water uptake and essential mineral nutrients from culture media. Also increment of the toxic effect of sodium at high salt concentration level caused physiological adverse effects that resulted in high reduction in photosynthesis, enzymatic process and protein synthesis, which resulted in limited growth and delayed leaf area expansion. Increments of TDW were observed in primed seeds in contrast to the unprimed seeds. This might be a result of improvement of plant water status and minimizing the toxic effects of $\mathrm{Na}^{+}$ resulted in maximum dry weight. The results in this study agree with those found by Achakzai et al. (2010); and Mahdy et al., (2012).
The data presented in Table (1) proved that the SI was exponentially dropped as the salt stress increased. However, the rate of decrement was more abundant at 1,2 , and $4 \mathrm{~g} / \mathrm{L} \mathrm{NaCl}$ and reduced at the higher salt exposure 6 and $8 \mathrm{~g} / \mathrm{L} \mathrm{NaCl}$. On average, the drop percentage of salt index (SI) at the respective salinity level were 64.6, 45.80 and 34.40; compared with 24.80 and 19.50 at the higher level. The documented data on TDW and SI criteria (Figs 3) revealed that the reaction of corn seedling, with respect to the priming and salinity treatments imposed similar trend. The data also proved that priming seeds in saline solution was beneficial, not only to improve the TDW, but also was creative to enhance the salt tolerance index across the imposed salinity levels (Fig.3). These results agree with the findings of Saboora and Kiarostami, (2006) and Carpıcı et al., (2009).

\section{2- Plant chemical composition}

\subsection{Sodium and potassium concentrations}

Sodium and potassium content were significantly affected by increasing salinity levels (Fig.4).

The results detected on plumule sodium content (PSC) showed successive $\mathrm{Na}$ accumulation, as $\mathrm{NaCl}$ concentration levels are increased. The potential of $\mathrm{Na}$ increase was, however, determinal and seriously affected plant growth as revealed from TDW data (Table 1). The maximum PSC was clearly manifested at $8 \mathrm{~g} / \mathrm{L} \mathrm{NaCl}$, whereas the average increase accounted for $103 \%$. A positive correlation of $\mathrm{Na}^{+}$ion accumulation in the plumule with increasing levels of salinity was observed in the present study. The opposite trend was observed for $\mathrm{K}^{+}$accumulation when exposed to salinity (Fig.4 B).Unlike the trend appeared on plumule sodium content (Fig.4 A). The result showed that plumule potassium content (PPC) was relatively higher for the primed than the unprimed seed treatments (Fig.4 B), across all salinity levels. The LSD comparisons clarified that at a certain level of salt exposure, the differences in PPC between the primed and unprimed treatments were significant at $p<0.01$ (Fig.4 B). In contrast, the result of the documented PSC proved that the differences between the respective treatments, particularly, at the control as well for 1 and $2 \mathrm{~g} / \mathrm{L} \mathrm{NaCl}$ were limited and not significant. The negative effect of salinity was suggested as to be the result of water loss, ion imbalance (Kurth et al., 1986). Physiological mechanisms conferring exclusion that operate at the cellular and whole plant level have been described in the literature and with particular reference to selectivity for $\mathrm{K}^{+}$over $\mathrm{Na}^{+}$(Tester and Davenport, 2003). 

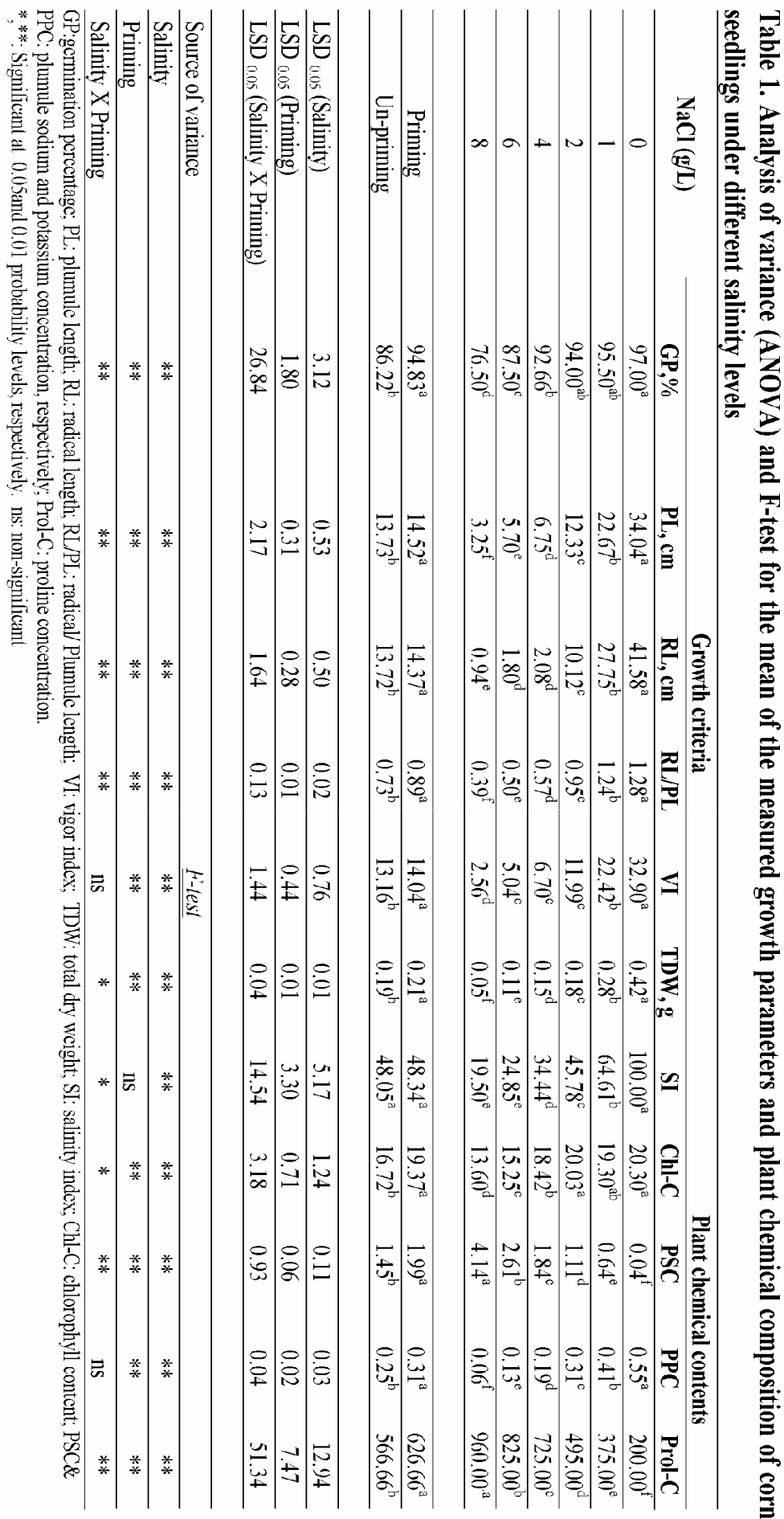

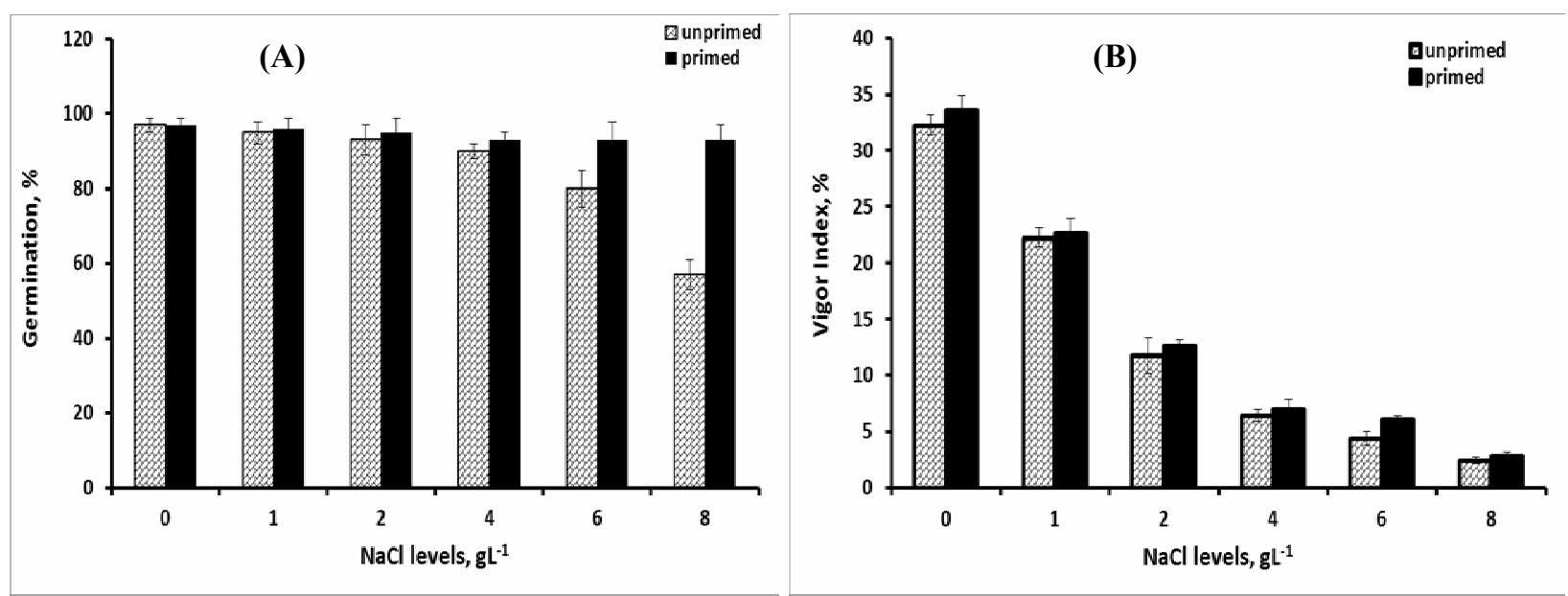

Fig. 1. Germination percentage (A) and vigor index (B) of corn as influenced by the interaction effect of salinity levels and priming treatments.
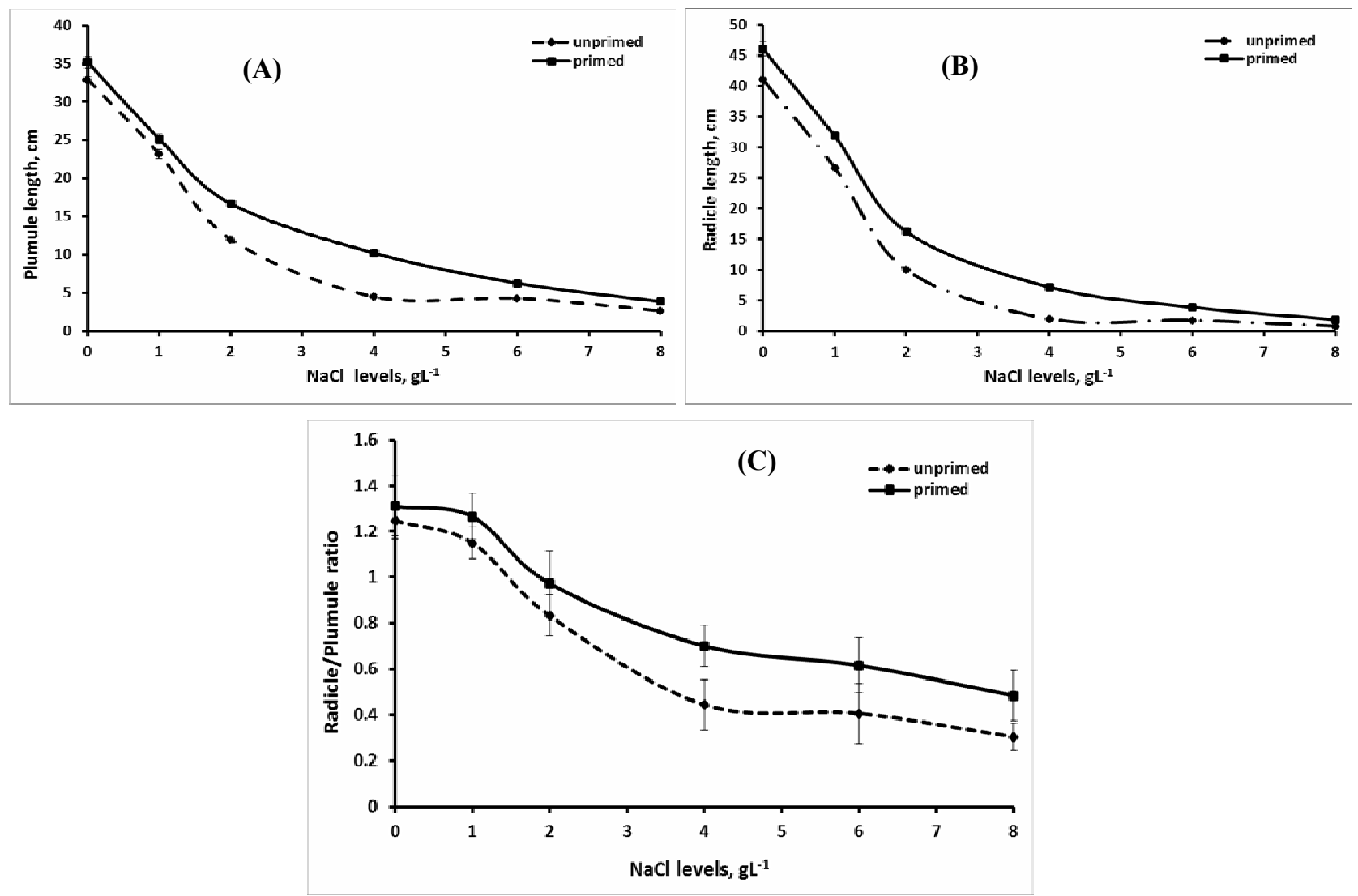

Fig. 2. Plumule (A) and radicle (B) lengths, and radicle/ Plumule ratio (C) of corn as influenced by the interaction effect of salinity levels and priming treatments. 

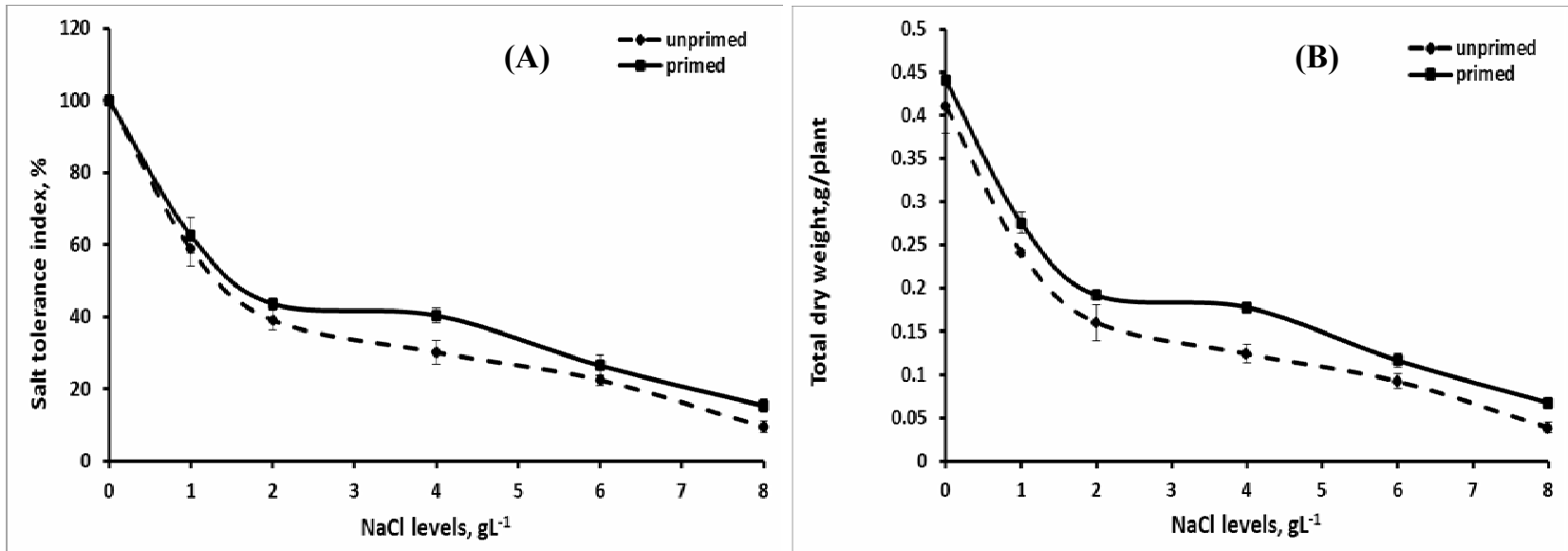

Fig. 3. Total dry weight (A) and salt tolerance index (B) of corn as influenced by the interaction effect of salinity levels and priming treatments.
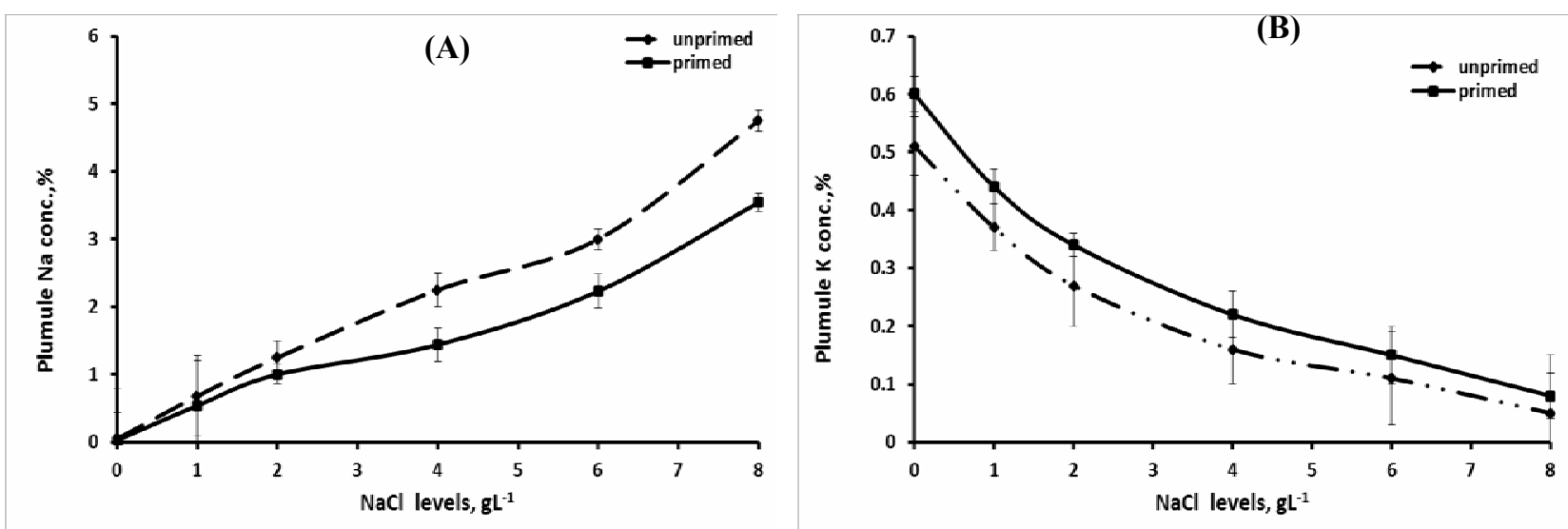

Fig. 4. Plumule sodium (A) and potassium concentrations (B) of corn as influenced by the interaction effect of salinity levels and priming treatments.
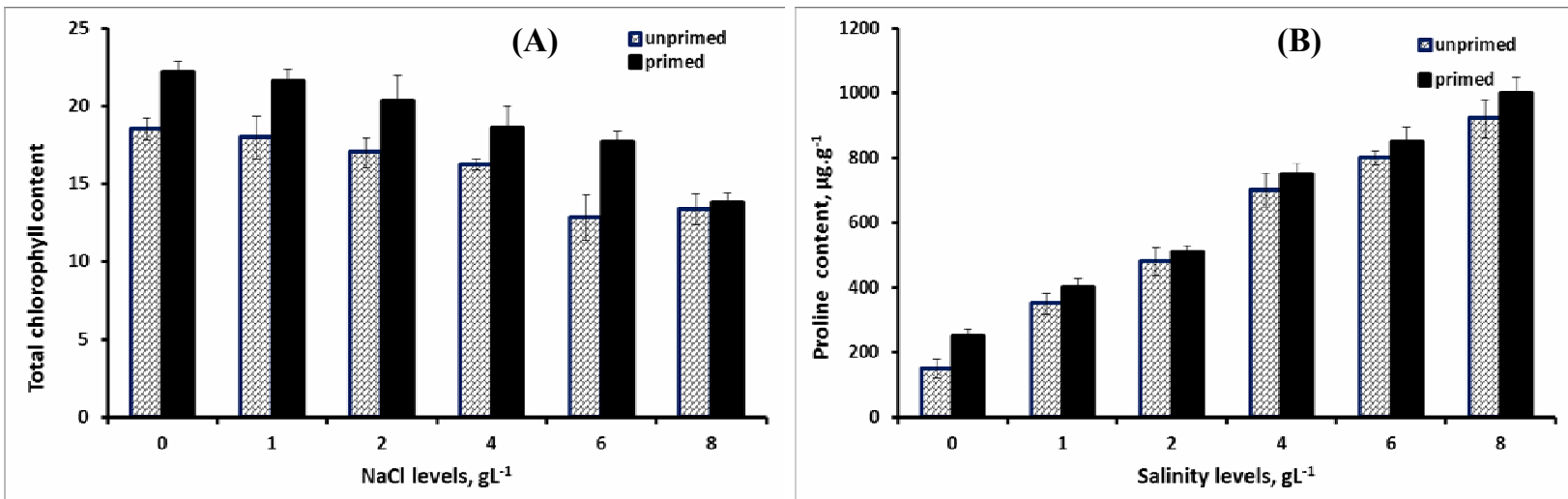

Fig. 5. Total chlorophyll (A) and proline content (B) of corn as influenced by the interaction effect of salinity levels and priming treatments. 


\subsection{Total chlorophyll and proline contents}

The data given in Table (1) showed that limited variations were detected on chlorophyll content (Chl-c), when the salinity level was increased up to $2 \mathrm{~g} / \mathrm{L} \mathrm{NaCl}$. Furthermore, the subsequent increment of salt stress exerted remarkable depressive effects on Chl-c (Table 1). Relative to the control, the reduction in Chl-c at 4,6 and $8 \mathrm{~g} / \mathrm{L} \mathrm{NaCl}$ were, subsequently, averaged 9.2, 24.3, and $33.0 \%$ respectively, it is clear that chlorophyll content was significantly decreased with increasing of salinity levels and priming resulted in enhancing the relative chlorophyll content of the leaves from 0 to 8 $\mathrm{g} / \mathrm{L} \mathrm{NaCl}$ in primed relative to unprimed seeds (Fig.5A). The results showed that plants derived from primed seeds produced more chlorophyll, which indicates that these plants were more salt tolerant. The increase in the chlorophyll content for plants derived from primed seeds could be due to an increase in the number of chloroplasts in leaves or to moderate levels of toxic ions in leaves which cannot cause early leaf senescence or chlorophyll degradation. These results agree with those of Khan et al. (2010) and Mahdy et al., (2012)

The results showed that proline content (Prol-c) significantly increased $(p<0.01)$ across the salinity levels. The increases in prol-c at 1 and $2 \mathrm{~g} / \mathrm{L} \mathrm{NaCl}$ were 1.9 and 2.4 times the prol-c at control. The comparable increases at 4,6 and $8 \mathrm{~g} / \mathrm{L} \mathrm{NaCl}$ were, subsequently, 3.6, 4.1 and $4.8 \%$ times the control treatment (Table 1 ). The combined variable treatments indicated that the primed seeds in saline solution was beneficial to exhibit marked significant increase over the unprimed treatment, across the all salinity levels (Fig.5A). With an exception to the result detected at $8 \mathrm{~g} / \mathrm{L} \mathrm{NaCl}$ between the primed and unprimed treatments, the advantage of the seed priming was more abundant, exhibited marked significant differences over the unprimed treatment as the salinity levels increased up to $6 \mathrm{~g} / \mathrm{L} \mathrm{NaCl}$ (Fig.5A).The results in Fig. (5B) confirmed that proline content was much higher in primed seeds than in the unprimed, along all salinity levels. The LSD comparisons revealed that marked differences in proline content between the primed and unprimed treatments were clearly evident at 0 and $8 \mathrm{~g} / \mathrm{L} \mathrm{NaCl}$ (Fig.5B).Such variation were also recorded, but the differences were not significant at $(p<0.01)$ particularly, at the lower salinity level, ranking between 1 and $2 \mathrm{~g} / \mathrm{L} \mathrm{NaCl}$.

It has been reported that proline has a dual role in improving salt stress tolerance as it is able to act in a similar way to the peroxidase enzymes and scavenge reactive oxygen species (Zhu, 2001). High levels of free proline in plant may have had a protective effect on cells at a higher concentration of salts. Proline is a key osmolyte that contributes to osmotic adjustment and improves stress tolerance by protecting and stabilizing membranes and enzymes during stress conditions. Our results showed that priming seeds can especially be useful in arid crop growing areas to reduce the effects of salinity. These results coincided with the results of other researchers (Cha-um and Kirdmanee, 2009; Mahdy and Fathi, 2012).

\section{CONCLUSION}

Seed priming or osmo-conditioning is one of the physiological methods which improves seed performance and provides faster and synchronized germination. It is an easy, low cost and low risk technique, which is recently being used to overcome the salinity problem in agricultural lands. The present study showed that salt stress decreased seed germination, biomass and growth of corn seedlings due to ionic toxicity, decrease osmotic potential and oxidative stress. Priming is an effective technique to meet the demands of farmers during the installation of the cultivation in conditions of salt stress. Seed priming with $\mathrm{NaCl}$ improved germination and early growth of corn seeds. The obtained results showed that plants derived from primed seeds produced more chlorophyll, which indicate that these plants were more salt tolerant. The proline content (Prol.c) was significantly increased ( $p$ $<0.01$ ) across the salinity levels. The results confirmed that proline content was much higher in primed seeds than in unprimed, along all salinity levels. Primed seeds should be sown in saline media to increase germination and early growth of corn seeds. Future research should be directed towards elucidating the physiological and biochemical studies during salinity stress.

\section{REFERENCES}

Achakzai AK, Kayani SA, Hanif Z (2010): Effect of salinity on uptake of micronutrients in sunflower at early growth stage. Pakistan J.Bot. 42:129-139.

Afzal I, Rauf S, Basra SMA, Murtaza G (2008): Halopriming improves vigor, metabolism of reserves and ionic contents in wheat seedlings under salt stress. Plant Soil Environ.54:382-388.

Ahmadvand G, Soleimani F, Bijan Saadatian B, Pouya M (2012): Effects of seed priming on germination and emergence traits of two soybean cultivars under salinity stress. J. Basic Appl. Sci. Res3:234-241.

Akram M, Ashraf MY, Ahmad R, Waraich EA, Iqbal J, Mohsan M (2010): Screening for salt tolerance in maize (Zea mays L.) hybrids at an early stage. Pakistan J. Bot. 42:141-151.

Alian A, Altman A, Hever B. (2000): Genotypic difference in salinity and water stress tolerance of fresh market tomato cultivars. Plant Sci. 152:59-65. 
Almansouri M, Kinet JM, Lutts S. (2001): Effect of salt and osmotic stresses on germination in durum wheat (Triticum durum). Plant \& Soil. 231:243-254.

Ashraf M., Harris P.J.C. (2004): Potential biochemical indicators of salinity tolerance in plants. Plant Science, 166: 3-16.

Ashraf, M., McNeally, T. (1990). Improvement of salt tolerance in maize for selection and breeding. Plant Breeding, 104, 101-107.

Bates L.S., Waldren R.P., Teare I.D. (1973): Rapid determination of free proline for water-stress studies. Plant \& Soil, 39: 205-207.

Carpıcı E. B. , Celık N, Bayram G. (2009): Effects of salt stress on germination of some maize

(Zea mays L.) cultivars. African Journal of Biotechnology, 8 (19): 4918-4922.

Cha-um, S., Kirdmanee, C., (2008): Effect of osmotic stress on proline accumulation. Photosynthetic ability and growth of sugar cane (Saccarrum officinarum L.) plantlets. Pak J Bot 40: 2541-2552.

Cha-um, S., Kirdmanee, C, (2009): Effect of salt stress on proline accumulation, photosynthetic ability and growth of two maize cultivars. Pak J Bot 41: 87-98.

Cohort software. (1986). COSTAT statistical software version 6.4, usermanual, California, USA.

Cramer GR. (2002). Sodium-calcium interactions under salinity stress in Läuchli A, Lüttge salinity. Envirnomentplants. 4:205-227.

Elouaer MA, Hannachi C. (2012). Seed priming to improve germination and seedling growth of safflower (Carthamus tinctorius) under salt stress. Eurasian J. Biosci. 6:76-84.

Farooq M, Basra SMA, Saleem BA, Nafees M, Chishti, S.A. (2005): Enhancement of tomato seed germination and seedling vigour by osmopriming. Pakistan J. Agric. Sci. 42(3-4): 36-41.

Farooq M., Basra S.M.A., Karim H.A.,Afzal I.(2004): Optimization of seed hardening techniques for rice seed invigoration. Emir. J. Agric. Sci., 16:48-57.

Gupta B., Huang B. (2014): Mechanism of salinity tolerance in plants: Physiological, biochemical, and molecular characterization. International Journal of Genomics, 2014:Article number 701596.

International Rules for Seed Testing (ISTA) (2008): International Seed Testing Association Chapter 5: Germination test. pp 1-57.

Jones J. B.,(2001). Laboratory Guide of Conducting Soil Tests and Plant Analysis.CRC Press. New York, Washington D.C., USA.

Kader MA, Jutzi SC. (2004): Effects of thermal and salt treatments during imbibition on germination and seedling growth of Sorghum at $42 / 19^{\circ}$ C. J. Agron. Crop Sci. 190: 35-38.
Khajeh-Hosseini M, Powell AA, Bimgham IJ. (2003): The interaction between salinity stress and seed vigor during germination of soybean seeds. Seed Science Technology 31: 715-725.

Khan M.J., Jan M.T., Khan A.U., Arif M.,Shafi M., (2010 ): Management of saline sodic soils through cultural practices and gypsum. Pak. J. Bot.,42: 4143-4155.

Kronzucker H.J., Britto D.T. (2011): Sodium transport in plants: A critical review. New Phytologist, 189: 54-81.

Kurth, E., Cramer, G.R., Lauchli, A., Esptain, E., (1986): Effects of $\mathrm{NaCl}$ and $\mathrm{CaCl} 2$ on cell enlargement and cell production in cotton roots. Plant Physiol, 82: 1102-1106.

Maathuis F.J.M., Ahmad I., Patishtan J. (2014): Regulation of $\mathrm{Na}+$ fluxes in plants. Frontiers in Plant Sci., 2014: 467.

Mahdy, A.M., Fathi. N.O. (2012): Interactive Effects between Biofertilizer and Antioxidant on Salinity Mitigation and Nutrition and Yield of Okra Plants (Abelmoschus esculentus L.). J. Soil Sci. and Agric. Eng., Mansoura Univ.,43(2):189-205.

Mahdy,A.M.,Fathi,N.O.,Kandil,M.M., Elnamas, A.E.(2012): Synergistic Effects of Biofertilizers and Antioxidants on Growth and Nutrients Content of Corn under Salinity and Water-Deficit Stresses.Alex.Sci.Exck.J.33(4):292-304.

Mohammadi GR. (2009): The Influence of $\mathrm{NaCl}$ priming on seed germination and seedling growth of canola (Brassica napus L.) under salinity conditions. J. Agric. Environ. Sci. 5:696-700.

Nawaz, A., Amjad, M., Jahangir, M.M., Khan, M.S., Cui,H.W. and Hu, J. (2012) Induction of salt tolerance in tomato (Lycopersicon esculentum Mill.) seeds through sand priming. African Journal of Crop Science, 6: 11991203.

Neto AD, Tabosa JN. (2000): Salt stress in maize seedlings: I. Growth analisys. Revista Brasileira de Engenharia agrícola e Ambiental.4:159-164.

Radić S., Štefanić P.P., Lepeduš H., Roje V., Pevalek-Kozlina B. (2013): Salt tolerance of Centaurea ragusina L. is associated with efficient osmotic adjustment and increased antioxidative capacity. Environmental and Experimental Botany, 87: 39-48.

Rateb K. A. (2013): Effect of Salicylic Acid Foliar Application and Saline Irrigation Water on Soil Salinity and Productivity of Maize (Zea mays L.). Alex.Sci.Exch.34(3):332-342.

Roy S.J., Negrão S., Tester M. (2014): Salt resistant crop plants. Current Opinion in Biotechnology, 26: 115-124.

Ruan S, Xue Q, Tylkowska K. (2002): The Influence of Priming on Germination of Rice (Oryzo sativa L.) Seeds and Seedling Emergence and Performance in Flooded Soil. Seed Sci. Technol. 30: 61-67.

Saboora A, Kiarostami K (2006). Salinity ( $\mathrm{NaCl}$ ) Tolerance of Wheat Genotypes at Germination and Early Seedling Growth. Pak. J.Biological Sci. 9(11): 2009-2021. 
Souguir M., Hassiba F., Hannachi C. (2013): Effect of $\mathrm{NaCl}$ priming on seed germination of Tunisian fenugreek (Trigonella foenumgraecum L.) under salinity conditions. Journal of Stress Physiology \& Biochemistry, 9(2):86- 96.

Tester, M., R. Davenport. (2003): $\mathrm{Na}^{+}$tolerance and $\mathrm{Na}^{+}$ transport in higher plants. Ann. Bot 91: 503-550.
Varier A., Vari A.K., Dadlani M. (2010): The subcellular basis of seed priming. Current Science, 99(4).

Zhang J.L., Shi H.Z. (2013): Physiological and molecular mechanisms of plant salt tolerance. Photosynthesis Research, 115: 1-22.

Zhu, J.K.( 2001):Plant salt tolerance.Trends Plant Sci. 6:6671(http://cjm.nrc.ca)

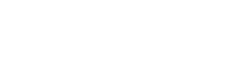

\section{أذاء النمو و التركيب الكيميأ لبادرات الذرة تختظروف الإجهاد الماله وقنية قع البذور}

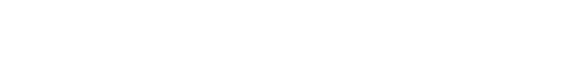

البذور المقوعة. وقد وجد ان البادرات الناتجة من البذور

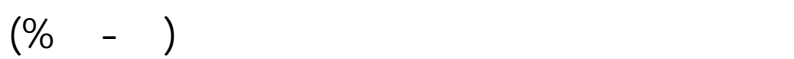

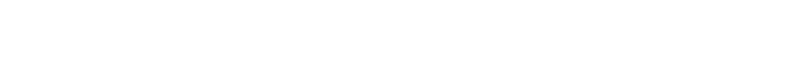

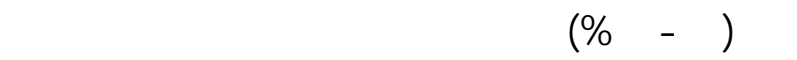

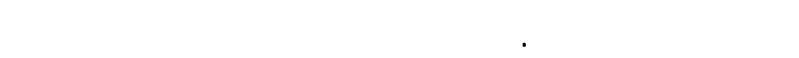

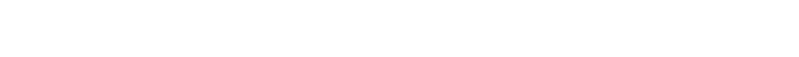

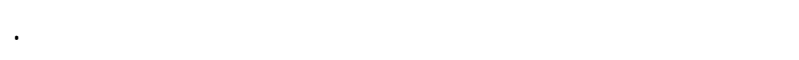
كذك، فإن محتوى البرولين في اوراق البادرات المشقة من

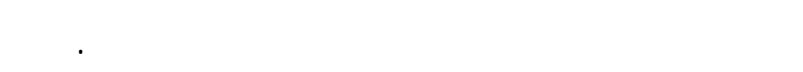
على النتائج للساقة فإن ققنية قع البذور فى محلول كلوريد

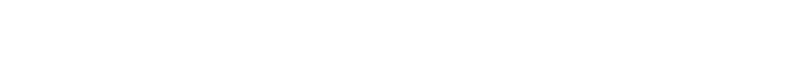
لمولجهة الإجهاد الملهى لتعسين أداء نبلت الذرة. الهالت الكشلة: ققنية قع البذور - الإجهاد الملهى بادرات الذرة - مقاييس النمو - التركيب الكيميائى.

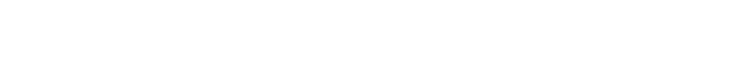
البذور على مقاييس النمو والتركيب الكيميائى لبادرات الذرة. لتققيق هذا الهذف مم ققع البذور فـ محلول كلوريد

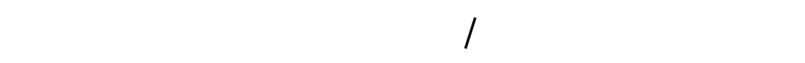

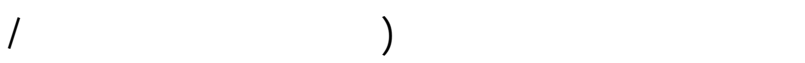

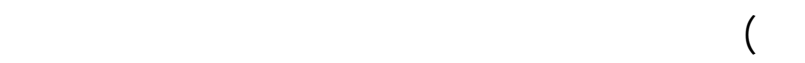

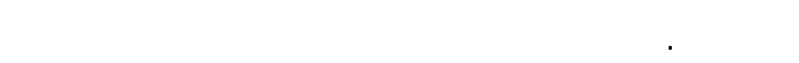
كلوريد الصويوم أدى اللى النخفاض نسبة إنبلت البذور

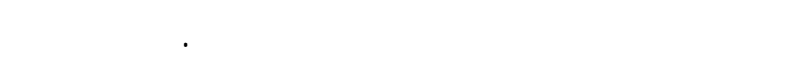
الانخفاض في نسبة الإنبات أعلى بكثير فى حالة البذورغير

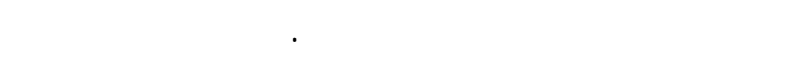
الجذير والريشة والوزن الجف الكلى ودليل تحمل الملوحة

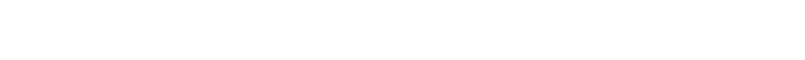

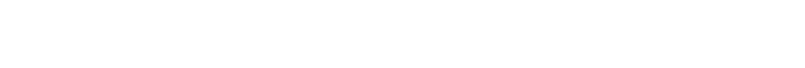

